\title{
ECONOMIC IMPACT OF THE KLEIN KaROO National ARTS FESTIVAL: INVESTIGATING THE APPLICATION OF DIFFERENT MODELS
}

\author{
Lukas van Wyk* \\ North-West University \\ lukas@profert.co.za
}

\author{
Melville Saayman\# \\ North-West University \\ melville.saayman@nwu.ac.za
}

\author{
Riaan Rossouw+ \\ North-West University \\ riaan.rossouw@nwu.ac.za
}

March 2012

\begin{abstract}
This article focuses on an economic assessment of the target obtained in South Africa regarding the Klein Karoo National Arts Festival (KKNK) applying both SAM and CGE models. Since both models have advantages and disadvantages, tourism economists are confronted with the predicament of determining which model is most suitable for application to any specific event. The findings reveal that when different models are applied to the same dataset from an event, the reported economic impact results differ significantly. Results indicate that considerations such as the data collection or compilation, expected output, research objectives and costs involved will determine the choice of a specific modelling framework. Data from a visitor survey conducted at the KKNK during 2010 were used in the analyses. This finding serves as a warning to assessors that economic impact results can be misleading and, therefore, the application thereof should be handled with the utmost care as the results can readily be misinterpreted by stakeholders.
\end{abstract}

Keywords

Arts festivals, Economic impact, Event tourism, Multiplier analysis, Regional CGE modelling, Social accounting Value at Risk, asymmetric GARCH, Extreme Value Theory, violations

*Lukas Wyk is a doctoral student at TREદS: Tourism Research in Economic Environs and Society, North-West University, Potchefstroom, South Africa.

\#Prof Melville Saayman is professor at TREદS: Tourism Research in Economic Environs and Society, North-West University, Potchefstroom, South Africa.

+Prof Riaan Rossouw is associate professor at the School of Economics, North-West University, Potchefstroom, South Africa. 


\section{INTRODUCTION}

In recent years, serious criticisms have been raised against the integrity of analyses conducted and the outcomes of economic impact studies. Crompton (1999) states bluntly that the integrity of many economic impact assessment studies is questionable. A number of researchers and consultants have succumbed to the temptation to adopt inappropriate procedures and assumptions in order to generate high economic impact results (Saayman \& Rossouw, 2008). This is done with the intention of portraying the event more favourably in the mind of taxpayers, elected officials and politicians to sustain or even increase the resources that were allocated. Comments such as, 'They are, in truth, the exact equivalent of an expert witness in a lawsuit who comes to testify in support of the side that is paying the expert's bill' and, 'The fees for the study are like a religious tithe paid to a priest to come and bless the endeavour', (Curtis, 1993:7), unfortunately confirm this opinion.

Crompton's (1999) research records a regrettable incident in which two independent tourism agencies were requested to evaluate the same event. Their reports contained disparate data resulting from the different approaches used for accounting for the use of public funds. Crompton is of the opinion that several underlying assumptions were made during the survey that had a substantial impact on the results. Whether these errors were made due to a genuine lack of understanding of the principles and procedures of an economic impact analysis, or were committed deliberately in order to generate a better picture, is somewhat immaterial. The result of either error is that the stakeholders were misled.

Literature indicates that various methods of assessment have been applied in numerous international studies to determine the economic impact of events. The most prevalent models used in these surveys include Input-Output (I-0), Social Accounting Matrix (SAM) and Computable General Equilibrium (CGE) models. As may be anticipated, each model is characterised with individual strengths and weaknesses.

This article will investigate the application of two of the aforementioned models (CGE and SAM) to determine the economic impact of the Klein Karoo National Arts Festival (hereafter referred to as KKNK).

\section{LITERATURE REVIEW}

In recent years, events and festivals have served as agents to accomplish objectives such as creating infrastructure, providing jobs, generating revenue, attracting investment, growing the arts, promoting a region and building a better image (Gursoy, Kim \& Uysal, 2004; Snowball, 2000). It becomes clear that an event influences several aspects of a community, and to a large extent, the economy of the community.

With regard to the most popular models in use, the literature reveals that, in applying models to estimate the economic impact of changes in an economy since 2000, two approaches, namely I0 and CGE models, were primarily used. Very often, SAM models, seen as an improvement on or expansion of I-0 models, were included in these referrals. The referrals refer to what the literature study revealed. Since 2000, I-0, SAM and CGE appear to be the most popular models used to assess the economic impact of events (including arts festivals). 
An I-0 model analyses the interdependence of industries in an economy. In its most basic form, it represents a system of linear equations that describes the distribution of an industry's product through the economy. This model is a comprehensive method for estimating the flow of money between sectors, sub-sectors, businesses, organisations and consumers, by monitoring the effects when various multipliers are applied (Reeves, 2002). The application of this model can measure the effects of macro-economic changes to the local economy and can investigate the monetary contribution of a certain sector to the local economy. Models can be tailored to specific conditions and economies or can be used to address economies of scale associated with changes of output. SAM models include both social and economic data of an economy and are regarded as broader-based models and their application is, therefore, favoured. I-0 tables, national income statistics and household income and expenditure statistics serve as the foundations of this model and they will, therefore, include typical national accounts that present different kinds of transactions within an economy (Cameron, 2003). Therefore, a SAM is broader than an I-0 table and typical national accounts, showing more detail about all kinds of transactions within an economy. However, an 1-0 table records economic transactions irrespective of the social background of the transactors. According to Cameron (2003), SAM models present a means for the logical arrangement of statistical information concerning the flow of income in a country's economy within a set period (usually for a period of 12 months).

White and Patriquin (2003) indicate that potential changes in one sector of an economy can have a significant impact on other sectors within the economy. By applying an I-0, SAM or CGE model, this sectoral impact can be estimated. Even though these models can be regarded as competitors, each model is applicable to specific situations and may even be complementary to each other, under certain conditions. For example, I-0 and SAM serve as building blocks to develop CGE models. Although CGE models require a large amount of data and are costly to implement, they overcome many of the limitations experienced with the I-0 and SAM models.

Cordier and Hecq (2008) define CGE models as a class of economic models that use actual economic data to predict how an economy might react in an event of changing policy, technology or other external factors. The inclusion of the SAM within a conceptual framework as provided by the CGE model (that contains the behavioural and technical relationships between variables within and among sets of accounts) could prove very useful when evaluating the economic effects of event policy changes and other economic phenomena.

Studies using a SAM for the assessment of the economic impact of events were conducted by Wagner (1997), Edmiston and Thomas (2004), Saayman, Rossouw and Saayman (2008), Rivera, Hara and Kock (2008), Saayman and Rossouw (2010), as well as by Kruger, Saayman, Saayman and Rossouw (2011). On the other hand, examples of studies that applied CGE models for evaluation are evident in the assessments conducted by various researchers such as Adams and Parmenter (1995), Narayan (2004), URS Finance and Economics (2004), Blake (2005), PricewaterhouseCoopers (2005), Dwyer, Forsyth and Spurr (2006a and 2006b), Bohlmann and Van Heerden (2008), Saayman and Rossouw (2008) and Rossouw and Saayman (2011). The question that remains is which one should be used or is the preferred approach for an arts festival?

\section{METHODOLOGY}

Since the initial festival in March 1995, the KKNK has evolved into a contemporary event that claims to be liberated from any political, cultural or religious affiliations. Approximately 1000 
artists perform in more than 200 productions and exhibitions over a period of eight days in the Klein Karoo town of Oudtshoorn. The festival is renowned for exciting open-air concerts that receive overwhelming support and accolades (Erasmus, Slabbert, Saayman, Saayman \& Oberholzer, 2010). The cited research confirms that the KKNK has the highest attendance rate of all the national festivals and is, therefore, recognised as the largest national arts festival in South Africa.

A destination-based survey, where interviews were held on-site during the event, was conducted. Participants responded to predetermined questions using the recall method. During the 2010 KKNK, data from 481 completed questionnaires were analysed. In order to ensure a scientific data analysis, the collected sets of data were coded in Microsoft ${ }^{\mathrm{TM}}$ Excel ${ }^{\mathrm{TM}}$ and processed by means of the Statistical Package for Social Science (SPSS).

\subsection{SAM multiplier model}

A SAM for the Western Cape was used to determine the direct, indirect and induced impact of visitor and organiser spending. Within the SAM framework, data are organised in a logically consistent manner. The SAM ties all expenditure made by the sector to the recipients of the relevant sector (Schwarm \& Cutler, 2003).

According to Saayman and Rossouw (2010), data from supply and use tables, national statistics and household income and expenditure statistics are required to compile a SAM. Providing a consistent framework for economy-wide models, a SAM generates detailed accounts for industries, workforce categories, institutional sub-sectors and various socio-economic household groups (Raa \& Sahoo, 2007). The various institutions are classified according to their socio-economic backgrounds despite their economic or functional contribution (Chowdhury \& Kirkpatrick, 1994).

The analysis was based on a SAM using a consistent and comprehensive dataset of all manual transactions among productive and institutional sectors of the province's economy. Using 2006 prices as a baseline, it distinguishes between 55 sectors, 12 household types and four ethnic groups. By making use of multipliers calculated from the SAM, the direct spending of visitors at the KKNK, as calculated in TABLE 1 , is converted to the linked increase in production, income and jobs in the region, represented by the indirect and induced impact.

\subsection{CGE model}

According to Liu and Chen (2004), CGE models combine the advantages of econometric I-O and SAM models that strengthen the theoretical basis of the modelling effort and, therefore, enable more precise policy analyses.

We use a Western Cape Province adaptation of the Paraná SAM model ${ }^{1}$ to execute our simulations. The simple SAM-based CGE model was constructed in GEMPACK (General Equilibrium Modelling PACKage) and adapted with data from the Western Cape $S A M^{2}$. The resulting model had 55 industrial sectors that produce 55 products. The model followed traditional neo-classical hypotheses of economic rationality, which means that each sector minimises its production costs subject to constant returns to scale, and input prices are given. Families used their income according to traditional functions of utility maximisation (Rolim \& Kureski, 2006).

Two regions for world trade were considered: the Rest of South Africa and the Rest of the World. Furthermore, imports were regarded as compound goods used in different proportions 
throughout all sectors. The model also considered that all payments for production factors were received by local families.

The matrix did not distinguish between activities and products. The entrance of commodities signified the purchase of compound goods formed by local and imported commodities. Imported products were only used directly by firms.

The specific model closure used for simulating the economic impact of the expenditure incurred by festival attendants at the KKNK in 2010 is a modified version of a standard short-run closure. Given the short-run nature of the simulation (owing to the short-run nature of the festival), investment is, therefore, held constant.

The shocks applied to the Western Cape economy were made by means of a simulation where the household consumption expenditure for the specified industries per spending group was increased by a certain percentage each. The scenarios (that is, different spending patterns per spending group) also simulated the overall impact of spending at the festival.

In order to reflect correctly the period under consideration, and to allow for the economic components as identified above, certain variables were held to be exogenous. Private consumption expenditure, capital stocks, technical change, tax rates and investment were all considered to be exogenous, while employment was regarded as endogenous. From a macroeconomic point of view, the impact on GDP and employment levels naturally attracts the most attention, but the results of the various shocks on an industry level are also of great value to business enterprises and investors.

The shocks applied in the various simulations and the respective magnitudes per sector were based on calculations made from expenditure figures taken from festival surveys as well as household expenditure figures per sector for the Western Cape. However, the precise magnitude of festival-specific capital and infrastructure expenditures remains a contentious issue. Therefore, the impact of these investments was not considered in the analysis.

\section{RESULTS OF THE SAM MULTIPLIER ANALYSIS}

The impact scenario chosen for this study is the impact of expenditures by visitors to the KKNK in Oudtshoorn in 2010 on the Western Cape economy. This application presents as near as possible a valid comparison of the two models (i.e. SAM and CGE), since visitor expenditures can be classified as final demand (final consumption expenditure of visitors) in both models.

The expenditure data by visitors have been deflated to 2006 values, allocated to industry sectors and converted to producers' values to be compatible with the Western Cape SAM. All the results are expressed in 2006 values. The implementation of the impact analyses in both models is similar, in that the visitor expenditures are incorporated into the models as final demand shocks.

\subsection{SAM: Total direct spending}

Direct spending by visitors at an event serves as the first input when assessing the economic impact that occurs. Visitor spending via a survey at the KKNK was sectioned into foreign visitors, local visitors and visitors from the rest of South Africa. Leakages, such as Value Added Tax (VAT) payments to SARS in Pretoria, commission payable to Computicket in Johannesburg and 
remuneration payable to artists residing outside the province, were excluded. After considering these adjustments, the direct spending (including visitors and organiser spending) totalled R47 252259.

Based on the information obtained from the questionnaires, the spending pattern of visitors who attended the 2010 KKNK could then be determined and the specific item spending (deflated to 2006 values) per visitor category is listed in TABLE 1.

TABLE 1: Total adjusted expenditure (ZAR, 2006 Prices) by visitors at the KKNK

\begin{tabular}{lrrrr}
\hline \multicolumn{1}{c}{ SPENDING ITEM } & FOREIGN & $\begin{array}{c}\text { LOCAL(WESTERN } \\
\text { CAPE) }\end{array}$ & REST OFRSA & TOTAL \\
\hline Accommodation & 108996 & 8340743 & 1713211 & 10162950 \\
Food and Restaurants & 72767 & 6935288 & 966461 & 7974515 \\
Liquor & 16887 & 3106701 & 433319 & 3556907 \\
Soft drinks & 37458 & 1451115 & 232805 & 1721378 \\
Performances & 23027 & 6174886 & 742661 & 6940575 \\
Purchases: Retailers & 73688 & 2626542 & 518216 & 3218446 \\
Purchases: Stalls & 81364 & 5962918 & 711582 & 6755863 \\
Amusement Parks / & 0 & 344317 & 67477 & 411794 \\
Adventure Activities & 58336 & 3543280 & 1046046 & 4647662 \\
Transport to KKNK & 0 & 410903 & 116792 & 527695 \\
Transport at the KKNK & 0 & 254998 & 39488 & 294487 \\
Parking & 0 & 1012730 & 27259 & 1039989 \\
Other & 472523 & 40164420 & 6615316 & 47252259 \\
\hline \multicolumn{1}{c}{ TOTAL } & & & &
\end{tabular}

Source: Authors'calculations based on visitor surveys

\subsection{SAM: Foreign expenditure}

The acquisition of goods and the utilisation of services by visitors from abroad contribute significantly to the revenue generation within the province. From the results displayed in TABLE 2, it is evident that the spending incurred by foreign visitors was mostly tourism related.

A direct impact was encountered in the trade and accommodation $(61.6 \%)^{3}$, transport and communication $(44.9 \%)^{4}$ and financial and business services $(17.5 \%)^{5}$ sectors. Applying the principle of backward linkages, the same sectors revealed a significant indirect and induced impact, namely for trade and accommodation (indirect R171 683, induced R114 934), transport and communication (indirect R46 245, induced R24 073) and the financial and business services (indirect R61 162, induced R37 376). 
TABLE 2: Impact through production multipliers (ZAR, 2006 prices) - foreign, local (Western (ape), rest of South Africa and total

\begin{tabular}{|c|c|c|c|c|c|}
\hline SECTOR & $\begin{array}{l}\text { DIRECT } \\
\text { IMPACT }\end{array}$ & $\begin{array}{l}\text { INDIRECT } \\
\text { IMPACT }\end{array}$ & $\begin{array}{l}\text { INDUCED } \\
\text { IMPACT }\end{array}$ & $\begin{array}{l}\text { TOTAL } \\
\text { IMPACT }\end{array}$ & $\begin{array}{l}\text { PERCENTAGE } \\
\text { (TOTAL) }\end{array}$ \\
\hline & \multicolumn{5}{|c|}{ FOREIGN } \\
\hline Agricultural & 0 & 664 & 350 & 1873 & $0.2 \%$ \\
\hline Mining & 0 & 42 & 48 & 209 & $0.0 \%$ \\
\hline Manufacturing & 0 & 21976 & 10058 & 56874 & $6.1 \%$ \\
\hline Electricity and water & 0 & 1037 & 762 & 3754 & $0.4 \%$ \\
\hline Construction & 0 & 980 & 321 & 2116 & $0.2 \%$ \\
\hline Trade and accommodation & 391159 & 171683 & 114934 & 539562 & $58.3 \%$ \\
\hline $\begin{array}{l}\text { Transport and } \\
\text { communication }\end{array}$ & 58336 & 46245 & 24073 & 127536 & $13.8 \%$ \\
\hline $\begin{array}{l}\text { Financial and business } \\
\text { services }\end{array}$ & 23027 & 61162 & 37376 & 185214 & $20.0 \%$ \\
\hline Community services & 0 & 2714 & 2256 & 8776 & $0.9 \%$ \\
\hline \multirow[t]{2}{*}{ TOTAL } & 472523 & 306503 & 190178 & 925913 & $100.0 \%$ \\
\hline & \multicolumn{5}{|c|}{ LOCAL (WESTERN CAPE) } \\
\hline Agricultural & 0 & 53885 & 28577 & 152431 & $0.2 \%$ \\
\hline Mining & 0 & 3479 & 3986 & 17201 & $0.0 \%$ \\
\hline Manufacturing & 0 & 1824469 & 836269 & 4731788 & $6.0 \%$ \\
\hline Electricity and water & 0 & 84496 & 62029 & 305726 & $0.4 \%$ \\
\hline Construction & 0 & 80822 & 26424 & 174463 & $0.2 \%$ \\
\hline Trade and accommodation & 28423307 & 12818428 & 8572440 & 40423000 & $51.4 \%$ \\
\hline $\begin{array}{l}\text { Transport and } \\
\text { communication }\end{array}$ & 3954182 & 3537918 & 1836204 & 9720252 & $12.4 \%$ \\
\hline $\begin{array}{l}\text { Financial and business } \\
\text { services }\end{array}$ & 6519203 & 6772681 & 4293980 & 20731316 & $26.4 \%$ \\
\hline Community services & 1267729 & 365167 & 668460 & 2399273 & $3.1 \%$ \\
\hline \multirow[t]{2}{*}{ TOTAL } & 40164420 & 25541344 & 16328368 & 78655449 & $100.0 \%$ \\
\hline & \multicolumn{5}{|c|}{ REST OF SOUTH AFRICA } \\
\hline Agricultural & 0 & 9604 & 5125 & 27270 & $0.2 \%$ \\
\hline Mining & 0 & 654 & 749 & 3234 & $0.0 \%$ \\
\hline Manufacturing & 0 & 322119 & 145932 & 833864 & $6.4 \%$ \\
\hline Electricity and water & 0 & 15605 & 11456 & 56464 & $0.4 \%$ \\
\hline Construction & 0 & 13406 & 4383 & 28938 & $0.2 \%$ \\
\hline Trade and accommodation & 4575593 & 2100265 & 1400460 & 6624442 & $50.8 \%$ \\
\hline $\begin{array}{l}\text { Transport and } \\
\text { communication }\end{array}$ & 1162838 & 754388 & 394013 & 2093805 & $16.1 \%$ \\
\hline Financial and business & 810138 & 1033000 & 648798 & 3151851 & $24.2 \%$ \\
\hline
\end{tabular}




\begin{tabular}{|c|c|c|c|c|c|}
\hline SECTOR & $\begin{array}{l}\text { DIRECT } \\
\text { IMPACT }\end{array}$ & $\begin{array}{l}\text { INDIRECT } \\
\text { IMPACT }\end{array}$ & $\begin{array}{l}\text { INDUCED } \\
\text { IMPACT }\end{array}$ & $\begin{array}{l}\text { TOTAL } \\
\text { IMPACT }\end{array}$ & $\begin{array}{c}\text { PERCENTAGE } \\
\text { (TOTAL) }\end{array}$ \\
\hline \multicolumn{6}{|l|}{ services } \\
\hline Community services & 66747 & 48287 & 59098 & 219841 & $1.7 \%$ \\
\hline TOTAL & 6615316 & 4297327 & 2670013 & 13039709 & $100.0 \%$ \\
\hline & \multicolumn{5}{|c|}{ TOTAL IMPACT } \\
\hline Agricultural & 0 & 64153 & 34052 & 181573 & $0.2 \%$ \\
\hline Mining & 0 & 4176 & 4783 & 20644 & $0.0 \%$ \\
\hline Manufacturing & 0 & 2168563 & 992259 & 5622526 & $6.1 \%$ \\
\hline Electricity and water & 0 & 101138 & 74246 & 365944 & $0.4 \%$ \\
\hline Construction & 0 & 95209 & 31127 & 205517 & $0.2 \%$ \\
\hline Trade and accommodation & 33366059 & 15090376 & 10087834 & 47587004 & $51.4 \%$ \\
\hline $\begin{array}{l}\text { Transport and } \\
\text { communication }\end{array}$ & 5175356 & 4338550 & 2254290 & 11941593 & $12.9 \%$ \\
\hline $\begin{array}{l}\text { Financial and business } \\
\text { services }\end{array}$ & 7352368 & 7866842 & 4980154 & 24068381 & $26.0 \%$ \\
\hline Community services & 1334475 & 416167 & 729813 & 2627890 & $2.8 \%$ \\
\hline TOTAL & 47252259 & 30145174 & 19188559 & 92621071 & $100.0 \%$ \\
\hline
\end{tabular}

\section{Source: Authors'SAM model results}

It should be noted that the direct effect of the expenditure by foreign visitors was $46.4 \%$, the indirect effect $33.1 \%$ and the induced effect $20.5 \%$ of the total increase in expenditure. Sectors affected by experiencing a significant impact were trade and accommodation (58.3\%), financial and business services (20.0\%) and transport and communication (13.8\%).

\subsection{SAM: Local (Western Cape) expenditure}

From the data collected (refer to TABLE 2), it was estimated that the total impact of local expenditure totalled R78 655 449. The sectors that benefited the most were trade and accommodation (51.4\%), financial and business services (26.4\%) and transport and communication (12.4\%). Of the total increase in expenditure in the province related to local spending, the direct impact represented $46.8 \%$, the indirect impact $32.5 \%$ and the induced impact $20.8 \%$.

TABLE 2 indicates that the direct impact on the province's economy as result of spending by local visitors was R40 164420 . Although nine activity sectors were identified, only four benefited from the direct impact, namely trade and accommodation (60.7\%), transport and communication (41.5\%), community services (39.7\%) and financial and business services (36.4\%). By applying the principle of backward linkages, large indirect (R25 541344 ) and induced (R16 328 368) impacts were also noted. In view of this, it may be assumed that in the absence of the festival, expenditure by local visitors would have been reduced and, therefore, a smaller amount would have been spent within the province. 


\subsection{SAM: Rest of South Africa expenditure}

As confirmed with the expenditure by foreign and local visitors, again the most significant impact occurs within the trade and accommodation (50.8\%), financial and business service $(24.2 \%)$ and transport and communication (16.1\%) sectors. The application of the backward linkages principle indicates that the trade and accommodation sector amounts to R4 575594 (60.4\%) when evaluating the direct impact. Significant indirect impacts are also noted in the construction (46.3\%), manufacturing (38.6\%), agricultural (35.2\%) and electricity (27.6\%) sectors.

The direct impact of visitors from the rest of South Africa is estimated at R6 615316 (46.6\%), the indirect impact R4 297327 (33.0\%) and the induced impact at R2 670013 (20.5\%). The total increase in local expenditure is estimated at R13 039709 . Sectors that benefited the most are similar to those of foreign visitors, namely trade and accommodation, financial and business services and transport and communication. The total of these three sectors represents approximately $91 \%$ of the total expenditure by KKNK visitors from the rest of South Africa.

\subsection{SAM: Total impact}

In order to evaluate the total economic impact within the province, the calculated direct impact needs to be adjusted by means of the multiplier effect.

TABLE 3: The impact of the KKNK on regional production

\begin{tabular}{|c|c|c|c|c|c|c|}
\hline SECTOR & $\begin{array}{l}\text { FOREIGN } \\
\text { SPENDING }\end{array}$ & $\begin{array}{c}\text { LOCAL } \\
\text { SPEN- } \\
\text { DING (WC) }\end{array}$ & $\begin{array}{c}\text { REST OF } \\
\text { SOUTH } \\
\text { AFRICA } \\
\text { SPENDING }\end{array}$ & $\begin{array}{l}\text { DIRECT } \\
\text { IMPACT }\end{array}$ & $\begin{array}{l}\text { PRO- } \\
\text { DUCTION } \\
\text { MULTI- } \\
\text { PLIERS }^{a}\end{array}$ & $\begin{array}{l}\text { TOTAL } \\
\text { IMPACT }\end{array}$ \\
\hline Agricultural & 0.000 & 0.000 & 0.000 & 0.000 & 2.823 & 0.182 \\
\hline Mining & 0.000 & 0.000 & 0.000 & 0.000 & 2.745 & 0.021 \\
\hline Manufacturing & 0.000 & 0.000 & 0.000 & 0.000 & 2.815 & 5.623 \\
\hline $\begin{array}{l}\text { Electricity and } \\
\text { water }\end{array}$ & 0.000 & 0.000 & 0.000 & 0.000 & 2.560 & 0.366 \\
\hline Construction & 0.000 & 0.000 & 0.000 & 0.000 & 3.003 & 0.206 \\
\hline $\begin{array}{l}\text { Trade and } \\
\text { accommodation }\end{array}$ & 0.391 & 28.423 & 4.576 & 33.390 & 2.840 & 47.587 \\
\hline $\begin{array}{l}\text { Transport and } \\
\text { communication }\end{array}$ & 0.058 & 3.954 & 1.163 & 5.175 & 2.754 & 11.942 \\
\hline $\begin{array}{l}\text { Financial and } \\
\text { business services }\end{array}$ & 0.023 & 6.519 & 0.810 & 7.352 & 2.684 & 24.068 \\
\hline Community services & 0.000 & 1.268 & 0.067 & 1.334 & 3.160 & 2.628 \\
\hline TOTAL & 0.473 & 40.164 & 6.615 & 47.252 & & 92.621 \\
\hline
\end{tabular}

Source: Authors'SAM model results

${ }^{a}$ Unit in R million excluding variable production multipliers 
The total impact of the festival on each of the province's economic sectors (as summarised in TABLE 3) was calculated by multiplying the direct economic impact in each sector by means of specific production multipliers. An estimated total impact of the festival within the province was then determined by means of adding the total impact values of the different sectors.

From TABLE 2 it can be noted that the direct impact (R47 252 259) increased to a total impact of R92 621071 when the indirect (R30 145 174) and induced impact (R19 188 559) are also taken into account. This represents an aggregated production multiplier of 1.96 . This implies that for every rand that visitors spent in the province, an additional 96 cents are generated in terms of indirect expenditure. In order to calculate the aggregated production multiplier, the total impact is divided by the direct impact.

In TABLE 4, specific household income multipliers for each activity sector are calculated and then multiplied with the values of the total sector's impact on family income due to the presentation of the KKNK. It is estimated that an annual remuneration total of R38 435193 would have been lost to Western Cape households should the festival not have taken place. The aggregated income multiplier is valued at 0.39 and this can be interpreted as an increment of the Western Cape family's income for each rand that is spent by visitors to the province.

Labour, as an important factor in the production process, is also positively impacted. As can be seen from TABLE 5, in addition to the number of employees directly involved in the event, 760 jobs may be exclusively dependent on the festival. These employment opportunities include direct, indirect and induced impacts, and represent both full- and part-time jobs. The sectors that would be the most affected by the absence of the festival are trade and accommodation, financial and business services and community services.

TABLE 4: The impact of the KKNK on family income

\begin{tabular}{|c|c|c|c|c|c|}
\hline \multirow[b]{2}{*}{ Sector } & \multirow{2}{*}{$\begin{array}{c}\text { Total } \\
\text { Impact } \\
\text { (R Million) }\end{array}$} & \multicolumn{4}{|c|}{ Direct Impacts (R Million) and Induced } \\
\hline & & $\begin{array}{l}\text { Rest of the } \\
\text { Households }\end{array}$ & $\begin{array}{l}\text { Low-Income } \\
\text { Households }\end{array}$ & $\begin{array}{c}\text { Total } \\
\text { Households }\end{array}$ & $\begin{array}{c}\text { Percentage } \\
\text { (Total) }\end{array}$ \\
\hline Agricultural & 0.182 & 0.005 & 0.062 & 0.067 & $0.2 \%$ \\
\hline Mining & 0.021 & 0.000 & 0.008 & 0.008 & $0.0 \%$ \\
\hline Manufacturing & 5.623 & 0.117 & 1.967 & 2.085 & $5.4 \%$ \\
\hline Electricity and water & 0.366 & 0.007 & 0.126 & 0.133 & $0.3 \%$ \\
\hline Construction & 0.206 & 0.004 & 0.069 & 0.074 & $0.2 \%$ \\
\hline $\begin{array}{l}\text { Trade and } \\
\text { accommodation }\end{array}$ & 47.587 & 1.031 & 18.532 & 19.563 & $50.9 \%$ \\
\hline $\begin{array}{l}\text { Transport and } \\
\text { communication }\end{array}$ & 11.942 & 0.195 & 4.853 & 5.048 & $13.1 \%$ \\
\hline $\begin{array}{l}\text { Financial and } \\
\text { business services }\end{array}$ & 24.068 & 0.355 & 9.977 & 10.332 & $26.9 \%$ \\
\hline Community services & 2.628 & 0.098 & 1.029 & 1.127 & $2.9 \%$ \\
\hline TOTAL & 92.621 & 1.813 & 36.622 & 38.435 & $100.0 \%$ \\
\hline
\end{tabular}

Source: Authors'SAM model results 
It is important to bear in mind that the I-0 tables can only be used to this effect when the job coefficients are known. This requires the existence of estimates for the relationship jobproduction. Therefore, based on the values presented previously, an alternative method can be applied to present an estimate of the festival's impact at the level of jobs in the region.

TABLE 5: The impact of the KKNK on employment

\begin{tabular}{lccc}
\multicolumn{1}{c}{ SECTOR } & $\begin{array}{c}\text { TOTAL IMPACT } \\
\text { (RMILLION) }\end{array}$ & $\begin{array}{c}\text { LABOUR } \\
\text { MULTIPLIERS }\end{array}$ & $\begin{array}{c}\text { EPUIVALENTJOBS } \\
\text { (NUMBER) }\end{array}$ \\
\hline Agricultural & 0.182 & 20.93 & 4 \\
\hline Mining & 0.021 & 4.82 & 0 \\
\hline Manufacturing & 5.623 & 3.63 & 2 \\
\hline Electricity and water & 0.366 & 4.91 & 2 \\
\hline Construction & 0.206 & 11.26 & 529 \\
\hline Trade and accommodation & 47.587 & 11.12 & 20 \\
\hline $\begin{array}{l}\text { Transport and } \\
\text { communication }\end{array}$ & 11.942 & 1.67 & 142 \\
\hline $\begin{array}{l}\text { Financial and business } \\
\text { services }\end{array}$ & 24.068 & 5.89 & 41 \\
\hline Community services & 2.628 & 15.54 & $\approx 760$ \\
\hline TOTAL & 92.621 & & \\
\hline
\end{tabular}

Source: Authors'SAM model results

The labour multiplier indicates the number of job opportunities that will be created as a result of change in production of 1 million by a particular activity.

This can be done by converting the event's expenditure in the region to equivalent job units. Although the input-output analysis can be used for this purpose, Wilson and Raymond (1973) proposed an equation that allows the calculation of credible estimates for these values and which is given by:

$$
\text { Equivalent Jobs }=\sum \frac{S_{i}}{R_{i}}
$$

where $S_{i}$ represents the amount of expenditure in the activity sector $I$ and $R_{i}$ represents the average business volume per worker of the sector $i$. Based on this equation, and using data from Statistics South Africa relative to the business volume and jobs by activity sector in the province in 2006, it was possible to obtain an estimate of the impact of the festival with regard to the regional job level (refer to TABLE 6).

TABLE 6 indicates the number of employment opportunities that were generated within the regional economy as a result of the festival being presented. In addition to the number of employees directly employed by the festival organisers, a total of 946 job opportunities may depend upon the festival. 
TABLE 6: The regional impact of the KKNK on the level of employment

\begin{tabular}{lccc}
\hline \multicolumn{1}{c}{ SECTOR } & $\begin{array}{c}\text { TOTAL IMPACT } \\
\text { (RMILLION) }\end{array}$ & $\begin{array}{c}\text { TRANSACTION VOLUMEI } \\
\text { VOLUME OF JOBS }\end{array}$ & $\begin{array}{c}\text { EPUIVALENT JOBS } \\
\text { (NUMBER) }\end{array}$ \\
\hline Agricultural & 0.182 & 0.019 & 10 \\
Mining & 0.021 & 7.905 & 0 \\
Manufacturing & 5.623 & 2.512 & 2 \\
Electricity and water & 0.366 & 0.009 & 43 \\
Construction & 0.206 & 0.061 & 3 \\
Trade and & 47.587 & 0.076 & 627 \\
accommodation & 11.942 & 0.416 & 29 \\
Transport and \\
communication \\
Financial and business & 24.068 & 0.126 & 191 \\
services \\
Community services
\end{tabular}

Source: Authors'calculations

\section{RESULTS OF THE CGE MODEL ANALYSIS}

The assessment after applying a CGE model in order to determine the economic impact of the KKNK will now be discussed in terms of its total direct spending and simulated results.

\subsection{CGE: Total direct spending}

When applying the CGE model, the local economy was shocked by stimulating the household consumption expenditures for the specified industries per spending group by means of increasing each by a specific percentage. The different spending patterns per spending group also stimulated the overall impact of spending at the festival. The results after applying shocks are summarised in TABLE 7.

\subsection{CGE: Western Cape wide macro-economic effects}

When interpreting the findings of the shock to the Western Cape economy, it is essential to keep the type of model closure, or assumptions under which this simulation is run, in mind. In the simulated scenario, the impact of the increased demand for the relevant goods and services is measured. TABLE 8 presents a summary of selected macro-economic results obtained for the given shocks applied to the economy.

In the simulated scenario, the increase in household expenditure leads to higher GDP growth and employment, higher prices, lower exports owing to a decrease in competitiveness, and a negative impact on the balance of trade. Given the nature of the shock and model closure, these results are to be expected. Prices increase in this scenario because of the increase in demand for goods. 
TABLE 7: Spending of visitors at the KKNK (\% change)

\begin{tabular}{lcccc}
\hline \multicolumn{1}{c}{ SECTORS WHERE SPENDING WAS INCURRED } & FOREIGN & LOCAL (WC) & $\begin{array}{c}\text { REST OF } \\
\text { RSA }\end{array}$ & TOTAL \\
\hline Trade & $0.001 \%$ & $0.020 \%$ & $0.003 \%$ & $0.023 \%$ \\
Accommodation & $0.002 \%$ & $0.134 \%$ & $0.024 \%$ & $0.159 \%$ \\
Transport services & $0.001 \%$ & $0.012 \%$ & $0.004 \%$ & $0.016 \%$ \\
Business activities & $0.001 \%$ & $0.021 \%$ & $0.003 \%$ & $0.023 \%$ \\
Activities / services & $0.001 \%$ & $0.072 \%$ & $0.004 \%$ & $0.075 \%$ \\
$\begin{array}{l}\text { Total increase in HH expenditure due to } \\
\text { festival }\end{array}$ & $0.006 \%$ & $0.258 \%$ & $0.036 \%$ & $0.297 \%$ \\
\hline
\end{tabular}

Source: Authors'calculations based on visitor surveys

The increase in productivity owing to the increased demand enables output to increase relative to inputs. Growth in GDP and employment improves because of the relatively cheaper cost of production. Higher prices in the economy would weaken the real exchange rate of the country, decrease its competitiveness in international trade and lead to a lower demand for domestic exports. This increase in the cost of a specific parcel of the provincial labour force led to a $0.011 \%$ increase of the real provincial GDP and a $0.05 \%$ nominal increase. It shows only a small effect over total employment, yet it provided a $0.063 \%$ increase in real household consumption.

TABLE 8: Summary of results for scenarios - provincial and sectoral level impacts

\begin{tabular}{lcccc}
\hline $\begin{array}{c}\text { MACRO-ECONOMIC } \\
\text { EFFECTS }\end{array}$ & FOREIGN & $\begin{array}{c}\text { WESTERN CAPE } \\
\text { PROVINCE }\end{array}$ & REST OFRSA & TOTAL \\
\hline Western Cape Economy & ZAR & ZAR & ZAR & ZAR \\
Real GDP & 1.804635 & 46343654 & 8.660 .298 & 56.808 .587 \\
$\%$ Change & 0.000 & 0.009 & 0.001 & 0.011 \\
\hline Production & 1423741 & 36689145 & 6809058 & 44077727 \\
\%Change & 0.000 & 0.008 & 0.001 & 0.009 \\
\hline $\begin{array}{l}\text { Employment }(\#) \\
\text { \%Change }\end{array}$ & 5 & 198 & 23 & 222 \\
\hline Consumer prices & 0.000 & 0.017 & 0.003 & 0.020 \\
\%Change & - & - & - & - \\
\hline Price of labour & 0.001 & 0.033 & 0.006 & 0.041 \\
\%Change & 1036851 & 26639083 & 5024737 & 32700670 \\
\hline Total exports & 0.001 & 0.033 & 0.006 & 0.041 \\
\%Change & -4613926 & -116202578 & -22044313 & -142860816 \\
\hline Competitiveness & -0.003 & -0.068 & -0.013 & -0.084 \\
\%Change & - & - & - & - \\
\hline
\end{tabular}




\begin{tabular}{|c|c|c|c|c|}
\hline $\begin{array}{c}\text { MACRO-ECONOMIC } \\
\text { EFFECTS }\end{array}$ & FOREIGN & $\begin{array}{l}\text { WESTERN CAPE } \\
\text { PROVINCE }\end{array}$ & REST OF RSA & TOTAL \\
\hline Balance of trade & -333819 & -8568033 & -1641279 & -10543131 \\
\hline$\%$ Change & -0.001 & -0.031 & -0.006 & -0.038 \\
\hline \multicolumn{5}{|l|}{$\begin{array}{l}\text { Sector effects Value } \\
\text { added (Price) }\end{array}$} \\
\hline Natural Resources & 3061 & 22747 & 15497 & 47047 \\
\hline$\%$ Change & 0.000 & 0.001 & 0.000 & 0.002 \\
\hline Manufacturing & 138221 & 3544921 & 673828 & 4290113 \\
\hline$\%$ Change & 0.001 & 0.024 & 0.004 & 0.029 \\
\hline \multicolumn{5}{|l|}{ Employment (Volume) } \\
\hline Natural Resources & -1 & -36 & -6 & -42 \\
\hline \multirow[t]{2}{*}{$\%$ Change } & -0.001 & -0.022 & -0.004 & -0.027 \\
\hline & ZAR & ZAR & ZAR & ZAR \\
\hline Manufacturing & -3 & -80 & -14 & -95 \\
\hline$\%$ Change & -0.001 & -0.039 & -0.007 & -0.047 \\
\hline Services & 9 & 313 & 43 & 359 \\
\hline$\%$ Change & 0.001 & 0.030 & 0.005 & 0.036 \\
\hline \multicolumn{5}{|l|}{ Household effects } \\
\hline $\begin{array}{l}\text { Real household } \\
\text { consumption }\end{array}$ & 649835 & 17570537 & 3215850 & 21111304 \\
\hline \%Change & 0.002 & 0.053 & 0.010 & 0.063 \\
\hline
\end{tabular}

\section{Source: Authors' CGE model results}

TABLE 8 shows a relatively large increase in production and imports. This is mostly due to the respective increase in demand for goods and related productivity. The changes in investment and inventory levels are zero because of the nature of the short-run model closure used in this simulation. In order to fully understand the magnitude and direction of change to macroeconomic variables such as GDP, employment and exports caused by the simulated shocks, it is essential to look at the disaggregated micro-economic or industry-specific results. The following tables in this section present a view of the changes in activity levels of selected industries.

\subsubsection{CGE: Foreign expenditure}

TABLE 9 indicates that the increase in output of Rl 423741 can be ascribed to foreign expenditure and represents only $3.23 \%$ of the increase in output by all spending groups. The financial and business services as well as the transport and communication sectors reveal an increase in output of $0.002 \%$, the largest for this spending group. All remaining sectors reflect a minor impact. 
TABLE 9: Aggregate sectoral level impacts (structural effects for the regional model only) foreign

\begin{tabular}{|c|c|c|c|c|c|c|c|c|}
\hline $\begin{array}{c}\text { EFFECTOF } \\
\text { INCREASED } \\
\text { EXPENDITURE DUE }\end{array}$ & \multicolumn{2}{|c|}{ VALUE ADDED } & \multicolumn{2}{|c|}{ EXPORTS } & \multicolumn{2}{|c|}{ IMPORTS } & \multicolumn{2}{|c|}{ EMPLOYMENT } \\
\hline $\begin{array}{l}\text { Sector annualised } \\
\% \text { change }\end{array}$ & $\frac{\stackrel{\varrho}{\xi}}{\frac{\Xi}{\circ}}$ & : & $\frac{\stackrel{\mathscr{E}}{\xi}}{\frac{3}{\circ}}$ & : & 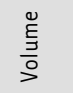 & 음 矛 & 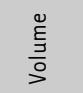 & 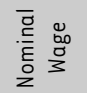 \\
\hline $\begin{array}{l}\text { Agriculture, forestry } \\
\text { and fishing (1) }\end{array}$ & - & 2871 & - & 5699 & - & - & -1 & 4102 \\
\hline$\%$ Change & 0.000 & 0.000 & -0.001 & 0.000 & 0.000 & 0.000 & -0.001 & 0.001 \\
\hline Mining (2-4) & - & 190 & - & 15 & - & 0 & 0 & 479 \\
\hline$\%$ Change & -0.001 & 0.000 & 0.000 & 0.000 & 0.000 & 0.000 & -0.001 & 0.001 \\
\hline $\begin{array}{l}\text { Manufacturing (5- } \\
\text { 25) }\end{array}$ & & & & & - & 0 & -3 & 28144 \\
\hline$\%$ Change & -0.001 & 0.001 & -0.004 & 0.001 & 0.002 & 0.000 & -0.001 & 0.001 \\
\hline $\begin{array}{l}\text { Electricity \& water } \\
(26-27)\end{array}$ & - & & & & & & & \\
\hline$\%$ Change & 0.000 & 0.001 & 0.000 & 0.000 & 0.000 & 0.000 & 0.001 & 0.000 \\
\hline Construction (28) & - & 41272 & - & 0 & - & 0 & 0 & 6546 \\
\hline$\%$ Change & 0.000 & 0.001 & -0.002 & 0.001 & 0.000 & 0.000 & 0.000 & 0.001 \\
\hline $\begin{array}{l}\text { Trade \& } \\
\text { accommodation } \\
(29-30)\end{array}$ & - & 205661 & - & 262234 & - & 0 & 0 & 23783 \\
\hline$\%$ Change & 0.000 & 0.001 & -0.005 & 0.001 & 0.002 & 0.000 & 0.000 & 0.001 \\
\hline $\begin{array}{l}\text { Transport \& } \\
\text { communication } \\
(31-32)\end{array}$ & - & 176576 & - & 113702 & - & 0 & 1 & 10915 \\
\hline$\%$ Change & 0.001 & 0.002 & -0.007 & 0.002 & 0.002 & 0.000 & 0.002 & 0.001 \\
\hline $\begin{array}{l}\text { Financial \& business } \\
\text { services }(33-35)\end{array}$ & - & 602579 & - & 362562 & - & 0 & 4 & 26327 \\
\hline$\%$ Change & 0.001 & 0.002 & -0.009 & 0.002 & 0.000 & 0.000 & 0.002 & 0.001 \\
\hline $\begin{array}{l}\text { Community services } \\
(36-37)\end{array}$ & - & 240593 & - & 1708 & - & 0 & 3 & 53764 \\
\hline$\%$ Change & 0.001 & 0.001 & -0.006 & 0.001 & 0.003 & 0.000 & 0.001 & 0.001 \\
\hline Industry average & - & 158193 & - & 95514 & - & 0 & 0 & 17278 \\
\hline$\%$ Change & 0.000 & 0.001 & -0.004 & 0.001 & 0.001 & 0.000 & -0.001 & 0.001 \\
\hline TOTAL & - & 1423741 & - & 859629 & - & - & 4 & 155501 \\
\hline
\end{tabular}

Source: Authors'CGE model results

\subsubsection{CGE: Local (Western Cape) expenditure}

In general, the expenditure by local visitors is excluded when calculating the economic impact of an event. However, in this simulation, the impact due to the spending of locals was calculated in order to obtain a more comprehensive assessment. As per TABLE 10, the local spending group 
contributes to the largest increase in output (R36 689 145). The most significant increase in output is experienced in the financial and business services sector $(0.058 \%)$. This sector is followed by transport and communication $(0.049 \%)$ and the community services sectors (0.038\%).

TABLE 10: Aggregate sectoral level impacts (structural effects for the regional model only) local

\begin{tabular}{|c|c|c|c|c|c|c|c|c|}
\hline $\begin{array}{c}\text { EFFECTOF } \\
\text { INCREASED } \\
\text { EXPENDITURE DUE }\end{array}$ & \multicolumn{2}{|c|}{ VALUE ADDED } & \multicolumn{2}{|c|}{ EXPORTS } & \multicolumn{2}{|c|}{ IMPORTS } & \multicolumn{2}{|c|}{ EMPLOYMENT } \\
\hline $\begin{array}{c}\text { Sector annualised } \\
\% \text { change }\end{array}$ & $\frac{\stackrel{\Xi}{E}}{\frac{\Xi}{\circ}}$ & 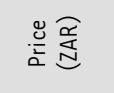 & $\frac{\stackrel{\Xi}{\xi}}{\rho}$ & 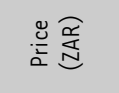 & 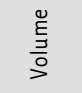 & : 을 & $\frac{\stackrel{\Perp}{\xi}}{\frac{5}{\circ}}$ & 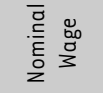 \\
\hline $\begin{array}{l}\text { Agriculture, forestry } \\
\text { and fishing (1) }\end{array}$ & - & 17.225 & - & 56992 & - & 0 & -34 & 105388 \\
\hline$\%$ Change & -0.005 & 0.001 & -0.008 & 0.002 & -0.006 & 0.000 & -0.017 & 0.033 \\
\hline Mining (2-4) & - & 5.522 & - & 438 & - & 0 & -1 & 12.315 \\
\hline$\%$ Change & -0.014 & 0.001 & -0.012 & 0.003 & -0.011 & 0.00 & -0.025 & 0.033 \\
\hline $\begin{array}{l}\text { Manufacturing (5- } \\
\text { 25) }\end{array}$ & - & 3544921 & - & 2.939 .575 & - & 0 & -80 & 723.078 \\
\hline$\%$ Change & -0.024 & 0.024 & -0.094 & 0.024 & 0.040 & 0.000 & -0.039 & 0.033 \\
\hline $\begin{array}{l}\text { Electricity \& water } \\
(26-27)\end{array}$ & - & 380.923 & - & 0 & - & 0 & 1 & 37031 \\
\hline$\%$ Change & 0.003 & 0.034 & 0.000 & 0.000 & 0.000 & 0.000 & 0.010 & 0.033 \\
\hline Construction (28) & - & 1061278 & - & - & - & 0 & -4 & 168186 \\
\hline$\%$ Change & -0.002 & 0.027 & 0.055 & 0.014 & 0.000 & 0.000 & -0.004 & 0.033 \\
\hline $\begin{array}{l}\text { Trade \& } \\
\text { accommodation } \\
(29-30)\end{array}$ & - & 5299721 & - & 6616357 & - & 0 & 15 & 611035 \\
\hline$\%$ Change & 0.006 & 0.034 & -0.131 & 0.033 & 0.041 & 0.000 & 0.006 & 0.033 \\
\hline $\begin{array}{l}\text { Transport \& } \\
\text { communication } \\
(31-32)\end{array}$ & - & 4801886 & - & 3085755 & - & 0 & 45 & 280428 \\
\hline$\%$ Change & 0.031 & 0.049 & -0.195 & 0.049 & 0.076 & 0.000 & 0.070 & 0.033 \\
\hline $\begin{array}{l}\text { Financial \& business } \\
\text { services }(33-35)\end{array}$ & - & 15064473 & - & 9032520 & - & 0 & 91 & 676404 \\
\hline$\%$ Change & 0.019 & 0.058 & -0.229 & 0.057 & 0.000 & 0.000 & 0.058 & 0.033 \\
\hline $\begin{array}{l}\text { Community services } \\
(36-37)\end{array}$ & - & 6513196 & - & 47697 & - & 0 & 147 & 1381322 \\
\hline$\%$ Change & 0.048 & 0.038 & -0.156 & 0.039 & 0.092 & 0.000 & 0.057 & 0.033 \\
\hline Industry average & - & 4076572 & - & 2419926 & - & 0 & 20 & 443910 \\
\hline$\%$ Change & -0.011 & 0.026 & -0.096 & 0.024 & -0.034 & 0.000 & -0.018 & 0.033 \\
\hline TOTAL & - & 36689145 & - & 21779335 & - & - & 178 & 3995188 \\
\hline
\end{tabular}

Source: $\quad$ Authors' CGE model results 


\subsubsection{CGE: Rest of South Africa expenditure}

Expenditure incurred by the rest of South Africa spending group accounts for approximately $15 \%$ of the total output increase (R6 809 058).

TABLE 11: Aggregate sectoral level impacts (structural effects for the regional model only) rest of South Africa

\begin{tabular}{|c|c|c|c|c|c|c|c|c|}
\hline $\begin{array}{c}\text { EFFECT OF } \\
\text { INCREASED } \\
\text { EXPENDITURE DUE }\end{array}$ & \multicolumn{2}{|c|}{ VALUE ADDED } & \multicolumn{2}{|c|}{ EXPORTS } & \multicolumn{2}{|c|}{ IMPORTS } & \multicolumn{2}{|c|}{ EMPLOYMENT } \\
\hline $\begin{array}{l}\text { Sector annualised } \\
\% \text { change }\end{array}$ & 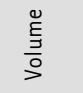 & : & $\frac{\stackrel{\Xi}{\xi}}{\frac{3}{5}}$ & : & $\frac{\stackrel{\varrho}{E}}{\frac{\Xi}{\circ}}$ & 음 总 & $\frac{\stackrel{\varrho}{\xi}}{\frac{3}{0}}$ & 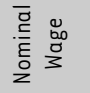 \\
\hline $\begin{array}{l}\text { Agriculture, forestry } \\
\text { and fishing (1) }\end{array}$ & - & 14354 & - & 22797 & - & 0 & -6 & 19897 \\
\hline$\%$ Change & -0.001 & 0.001 & -0.003 & 0.001 & 0.000 & 0.000 & -0.003 & 0.006 \\
\hline Mining (2-4) & - & 1143 & - & 82 & - & 0 & 0 & 2323 \\
\hline$\%$ Change & -0.003 & 0.000 & -0.002 & 0.001 & -0.002 & 0.000 & -0.005 & 0.006 \\
\hline $\begin{array}{l}\text { Manufacturing (5- } \\
\text { 25) }\end{array}$ & - & 673828 & - & 559800 & - & 0 & -14 & 136389 \\
\hline$\%$ Change & -0.004 & 0.004 & -0.018 & 0.004 & 0.008 & 0.000 & -0.007 & 0.006 \\
\hline $\begin{array}{l}\text { Electricity \& water } \\
(26-27)\end{array}$ & - & 76635 & - & 0 & - & 0 & 0 & 6985 \\
\hline$\%$ Change & 0.001 & 0.007 & 0.000 & 0.000 & 0.000 & 0.000 & 0.003 & 0.006 \\
\hline Construction (28) & - & 198498 & - & 0 & - & 0 & -1 & 31724 \\
\hline$\%$ Change & 0.000 & 0.005 & -0.010 & 0.003 & 0.000 & 0.000 & -0.001 & 0.006 \\
\hline $\begin{array}{l}\text { Trade \& } \\
\text { accommodation } \\
(29-30)\end{array}$ & - & 1004574 & - & 1270825 & - & 0 & 3 & 115255 \\
\hline$\%$ Change & 0.001 & 0.006 & -0.025 & 0.006 & 0.009 & 0.000 & 0.001 & 0.006 \\
\hline $\begin{array}{l}\text { Transport \& } \\
\text { communication } \\
(31-32)\end{array}$ & - & 902500 & - & 577987 & - & 0 & 8 & 52895 \\
\hline$\%$ Change & 0.006 & 0.009 & -0.037 & 0.009 & 0.014 & 0.000 & 0.013 & 0.006 \\
\hline $\begin{array}{l}\text { Financial \& business } \\
\text { services (33-35) }\end{array}$ & - & 2803302 & - & 1686701 & - & 0 & 17 & 127585 \\
\hline$\%$ Change & 0.004 & 0.011 & -0.043 & 0.011 & 0.000 & 0.000 & 0.011 & 0.006 \\
\hline $\begin{array}{l}\text { Community services } \\
(36-37)\end{array}$ & - & 1134224 & - & 8295 & - & 0 & 14 & 260549 \\
\hline$\%$ Change & 0.005 & 0.007 & -0.027 & 0.007 & 0.013 & 0.000 & 0.005 & 0.006 \\
\hline Industry average & - & 756562 & - & 458498 & - & 0 & 2 & 83731 \\
\hline$\%$ Change & -0.002 & 0.005 & -0.018 & 0.005 & 0.007 & 0.000 & -0.003 & 0.006 \\
\hline TOTAL & - & 6809058 & - & 4126486 & - & - & 20 & 753583 \\
\hline
\end{tabular}

Source: Authors' CGE model results 
From TABLE 11, the sectors that primarily contribute to the output increase are the financial and business services $(0.111 \%)$, transport and communication $(0.009 \%)$, electricity and water $(0.007 \%)$ and community services $(0.007 \%)$.

\subsubsection{CGE: Total impact}

In TABLE 12, the scenario clearly indicates the increased activity in all selected industries. The increased demand and spending seem to have a positive impact on most industries. When the interrelatedness among most industries is considered, this is to be expected. This specific scenario also illustrates that activity in the service industries naturally increases, but shows little influence on other industries.

\section{TABLE 12: Aggregate sectoral level impacts (structural effects for the regional model only) - total}

\begin{tabular}{|c|c|c|c|c|c|c|c|c|}
\hline $\begin{array}{c}\text { EFFECT OF } \\
\text { INCREASED } \\
\text { EXPENDITURE DUE }\end{array}$ & \multicolumn{2}{|c|}{ VALUE ADDED } & \multicolumn{2}{|c|}{ EXPORTS } & \multicolumn{2}{|c|}{ IMPORTS } & \multicolumn{2}{|c|}{ EMPLOYMENT } \\
\hline $\begin{array}{c}\text { Sector annualised } \\
\% \text { change }\end{array}$ & $\frac{\stackrel{\varrho}{\xi}}{\frac{5}{\circ}}$ & : & $\frac{\stackrel{\varrho}{\xi}}{\frac{5}{\circ}}$ & : & $\frac{\stackrel{\varrho}{E}}{\frac{\Xi}{0}}$ & 은 总 & $\frac{\stackrel{\Xi}{\xi}}{\frac{\Xi}{0}}$ & 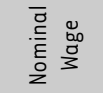 \\
\hline $\begin{array}{l}\text { Agriculture, forestry } \\
\text { and fishing (1) }\end{array}$ & - & 40192 & - & 88338 & - & 0 & -41 & 126845 \\
\hline$\%$ Change & -0.006 & 0.001 & -0.012 & 0.003 & -0.005 & 0.000 & -0.020 & 0.040 \\
\hline Mining (2-4) & - & 6855 & - & 534 & - & 0 & -1 & 14822 \\
\hline$\%$ Change & -0.016 & 0.002 & -0.014 & 0.004 & -0.013 & 0.000 & -0.030 & 0.040 \\
\hline $\begin{array}{l}\text { Manufacturing (5- } \\
\text { 25) }\end{array}$ & - & 4290113 & - & 3558104 & - & 0 & -95 & 870292 \\
\hline$\%$ Change & -0.028 & 0.029 & -0.114 & 0.028 & 0.049 & 0.000 & -0.046 & 0.040 \\
\hline $\begin{array}{l}\text { Electricity \& water } \\
(26-27)\end{array}$ & - & 466574 & - & 0 & - & 0 & 1 & 44570 \\
\hline$\%$ Change & 0.004 & 0.041 & 0.000 & 0.000 & 0.000 & 0.000 & 0.013 & 0.040 \\
\hline Construction (28) & - & 1275499 & - & 0 & - & 0 & -5 & 202427 \\
\hline$\%$ Change & -0.003 & 0.032 & -0.066 & 0.017 & 0.000 & 0.000 & -0.005 & 0.040 \\
\hline $\begin{array}{l}\text { Trade \& } \\
\text { accommodation } \\
(29-30)\end{array}$ & - & 6399215 & - & 8018299 & - & 0 & 18 & 735437 \\
\hline$\%$ Change & 0.007 & 0.040 & -0.159 & 0.040 & 0.051 & 0.000 & 0.007 & 0.040 \\
\hline $\begin{array}{l}\text { Transport \& } \\
\text { communication } \\
(31-32)\end{array}$ & - & 5797578 & - & 3723752 & - & 0 & 54 & 337522 \\
\hline$\%$ Change & 0.038 & 0.059 & -0.235 & 0.059 & 0.092 & 0.000 & 0.084 & 0.040 \\
\hline $\begin{array}{l}\text { Financial \& business } \\
\text { services (33-35) }\end{array}$ & - & 18051168 & - & 10829566 & - & 0 & 108 & 814115 \\
\hline$\%$ Change & 0.023 & 0.069 & -0.274 & 0.069 & 0.000 & 0.000 & 0.069 & 0.040 \\
\hline $\begin{array}{l}\text { Community services } \\
(36-37)\end{array}$ & - & 7750532 & - & 56602 & - & 0 & 161 & 1662550 \\
\hline
\end{tabular}




\begin{tabular}{|c|c|c|c|c|c|c|c|c|}
\hline $\begin{array}{c}\text { EFFECT OF } \\
\text { INCREASED } \\
\text { EXPENDITURE DUE }\end{array}$ & \multicolumn{2}{|c|}{ VALUE ADDED } & \multicolumn{2}{|c|}{ EXPORTS } & \multicolumn{2}{|c|}{ IMPORTS } & \multicolumn{2}{|c|}{ EMPLOYMENT } \\
\hline $\begin{array}{c}\text { Sector annualised } \\
\% \text { change }\end{array}$ & $\frac{\stackrel{\mathscr{E}}{\mathrm{g}}}{\mathrm{g}}$ & 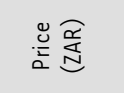 & 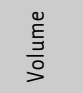 & : ํㅡㄴ & 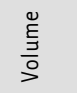 & 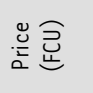 & 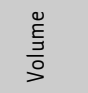 & 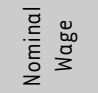 \\
\hline$\%$ Change & 0.052 & 0.045 & -0.186 & 0.046 & 0.106 & 0.000 & 0.062 & 0.040 \\
\hline Industry average & - & 4897525 & - & 2919466 & - & 0 & 22 & 534287 \\
\hline$\%$ Change & -0.014 & 0.031 & -0.116 & 0.029 & 0.042 & 0.000 & -0.021 & 0.040 \\
\hline TOTAL & - & 44077727 & - & 26275196 & - & - & 200 & 4808579 \\
\hline
\end{tabular}

\section{Source: Authors' CGE model results}

TABLE 12 also presents some detail on an aggregated level. Nominal wages all increase in tandem with the national inflation $(0.04 \%$, as in TABLE 12$)$ bearing in mind the assumption that the real wage rate is kept constant. Since the world price of goods is kept fixed (the numéraire ${ }^{6}$ by assumption), no change in national or sectoral level import prices will be observed. From TABLE 12, it is clear that at the sectoral level, there are losers as well as winners as result of the increase in expenditure due to the festival. Following the service industries that directly cater for visitors (29 to 37), electricity and water services exhibit the largest increase in output $(0.041 \%)$. This is possibly due to the relative share of tourist expenditure in the income base of these sectors, as well as the fact that these industries are directly and indirectly affected by an increase in expenditure by visitors. The transport sector also experiences a significant increase $(0.059 \%)$. Because of its link to the strongly stimulated service industries directly catering for visitors, manufacturing is an obvious example of the sectors that experience the indirect benefits of increased tourism. The electricity and water sector is a less obvious example. Its growth prospects are enhanced by the expansion of investment or increased demand induced by the additional tourism.

Certain sectors, such as the traded-goods industries, experienced output declines due to the increase in expenditure as a result of the festival. These sectors were adversely affected by the higher domestic prices within their specific industries that the expansion of tourism generated. Foremost examples include the traditional exporters (agriculture; mining; non-metallic mineral products; and basic and fabricated metal products) and the import-competing sectors such as textiles, clothing and footwear. Agriculture, forestry and fishing (traditional exporters), which might be expected to experience a significant decline because of the increase in imports, are saved indirectly to some extent from major declines by the increase in tourists' demand (indirectly) for their outputs.

TABLE 12 also displays the changes in employment by industry in the simulated scenario. The increase in expenditure and productivity increases the demand for labour in most industries. For all other sectors, employment increases in line with the increase in total output. 


\section{FINDINGS AND CONCLUSIONS}

This article compares the SAM and CGE models as assessment tools in order to evaluate the economic impact of the KKNK. The following findings resulted from this comparison of the two tools.

Firstly, this article reveals that the economic assessment by means of a SAM multiplier analysis and a CGE model generates different results. These differences became clear with regard to the results that were measured in terms of sectoral, visitors' residence and total impact (as per $T A B L E$ 13). The most significant difference in total impact is measured in the manufacturing, trade and accommodation, financial and business services as well as community services sectors. A very substantial difference with regard to the measured economic impact is noted within the local segment when the visitors' origins are considered by SAM and CGE models. The significant local support that is measured by both models may be ascribed to the geographical positioning of Oudtshoorn as the hosting town. The isolated location of the festival as well as the sparsely populated neighbouring provinces may contribute to the meagre support from other provinces and the obviously concentrated local representation.

\section{TABLE 13: Economic impact summary when applying a SAM and CGE model to the KKNK - foreign, local, rest of South Africa and total impact}

\begin{tabular}{|c|c|c|c|c|c|c|c|c|}
\hline SECTOR & \multicolumn{2}{|c|}{ FOREIGN } & \multicolumn{2}{|c|}{$\angle O C A L(W C)$} & \multicolumn{2}{|c|}{ REST OF RSA } & \multicolumn{2}{|c|}{ TOTAL } \\
\hline \multicolumn{9}{|c|}{ TOTAL IMPACT } \\
\hline & $S A M$ & $C G E$ & $S A M$ & $C G E$ & $S A M$ & $C G E$ & $S A M$ & $C G E$ \\
\hline Agricultural & 1873 & 2871 & 152431 & 17225 & 27270 & 14354 & 181573 & 40192 \\
\hline Mining & 209 & 190 & 17201 & 5522 & 3234 & 1143 & 20644 & 6855 \\
\hline Manufacturing & 56874 & 138221 & 4731788 & 3544921 & 833864 & 673828 & 5622526 & 4290113 \\
\hline $\begin{array}{l}\text { Electricity and } \\
\text { water }\end{array}$ & 3754 & 15778 & 305726 & 380923 & 56464 & 76635 & 365944 & 466574 \\
\hline Construction & 2116 & 41272 & 174463 & 1061278 & 28938 & 198498 & 205517 & 1275499 \\
\hline $\begin{array}{l}\text { Trade and } \\
\text { accommodation }\end{array}$ & 539562 & 205661 & 40423000 & 5299721 & 6624442 & 1004574 & 47587004 & 6399215 \\
\hline $\begin{array}{l}\text { Transport and } \\
\text { communication }\end{array}$ & 127536 & 176576 & 9720252 & 4801886 & 2093805 & 902500 & 11941593 & 5797578 \\
\hline $\begin{array}{l}\text { Financial and } \\
\text { business services }\end{array}$ & 185214 & 602579 & 20731316 & 15064473 & 3151851 & 2803302 & 24068381 & 18051168 \\
\hline $\begin{array}{l}\text { Community } \\
\text { services }\end{array}$ & 8776 & 240593 & 2399273 & 6513196 & 219841 & 1134224 & 2627890 & 7750532 \\
\hline TOTAL & 925913 & 1423741 & 78655449 & 36689145 & 13039709 & 6809058 & 92621071 & 44077727 \\
\hline \multicolumn{9}{|c|}{ ADDITIONAL JOB OPPORTUNITIES } \\
\hline \multicolumn{7}{|c|}{ Additional positions created (Excluding positions directly involved) } & 760 & 222 \\
\hline \multicolumn{7}{|c|}{ Employment opportunities lost if festival terminates } & 946 & \\
\hline
\end{tabular}

\section{Source: Authors'SAM and CGE model results}

In reflection of the calculated impact summarised in TABLE 13, the total impact when applying a SAM model is $110.13 \%$ higher (R48 543 344) than when applying a CGE model. The greater calculated impact when applying a SAM model is experienced in the local (R41 966304 or $114.38 \%$ ) and rest of South Africa (R6 230651 or $91.51 \%$ ) spending groups. However, in the foreign spending group, the impact calculated by applying the CGE model was larger 
(R1 423 741) than when calculated with the SAM model (R925 913). The calculated additional job opportunities created due to the KKNK taking place also differ considerably when applying the two different models. The SAM multiplier analysis reflects a much higher employment rate than that calculated with a CGE model. A possible reason for this is that the CGE model captures or accounts for crowding-out effects, while the SAM-based multiplier analysis does not. These differences again highlight the fact that economic assessors should pay meticulous attention when deciding on the most appropriate model to apply. When reporting on inflated figures, potentially misleading information could have negative consequences for all stakeholders.

Secondly, the methodological application of the assessment models indicates that, despite the enhancement of 1-0 models with multiplier effects, certain limitations still persist during applications. Therefore, the development of SAM models, based on I-0 models, is envisaged as an improvement. Application of these models is regarded as simple, quick, reliable, effective, efficient and flexible and the data required are generally readily available.

The methodological problems that may be experienced when applying SAM models incorporating I-0 tables are that:

- these tables are published on a national level although the application is needed on a regional level;

- published tables may be outdated;

- economic assessors of events should be aware of the possible hindrance where the geographical area for which the results are reported on and that of the I-0 table has no relation;

- when applying these models, limited, if any, price movements and supply constraints are accommodated;

- these models do not allow for any changes in the relationship between sectoral inputs and outputs;

- no integrated economic effects are taken into account;

- the assumption is made that the consumption preference of the host region equals that of tourists;

- impact estimates are often overestimated due to multipliers used that include consumption effects;

- the employment impact is often misinterpreted;

- capital expenditure not directly attributable to tourism is often included in the analysis; and

- value-added multipliers can be applied to spending that is calibrated in output terms.

CGE models are the most detailed and informative economic modelling technique available and are predominantly used in surveys where a large shock is to be applied to a complex economy (Adams \& Parmenter, 1999). These models are normally utilised to address specific what-if economy-wide scenarios and their application is often discouraged due to factors such as the mechanical complexity, the lack of available data and insufficient time to compile an assessment. Consequently, these models are applied during economic impact studies on national level. Of course, these national surveys have limited use during lower-level surveys. Although CGE models are data intensive and relatively expensive to set up and run, they seem to be the preferred economic impact-measuring tool as they may compensate for many of the limitations experienced by $1-0$ models, including supply constraints and price movements. 
Despite this apparent preference, analysts are often required to become familiar with CGE modelling software and techniques, despite these being much more complicated to implement and interpret.

Finally, this article clearly indicates the definite economic impact of events and the role of the various stakeholders such as event organisers, visitors, the hosting community and academics who have interests when an event is planned and presented. In view of the fact that the assessment outcomes between the various models differ, the application of these results will also influence the stakeholders on different levels. The possible over-inflated impact, as measured by a SAM model, may be favoured by event organisers to lobby for sponsorships, while others, such as residents and business owners within the hosting community, are misled. Reporting exaggerated economic impacts may render locals that offer services during the event despondent when they perceive their personal benefit as much less than those of the inflated figures. Moreover, when event organisers report higher impact values, sponsors are misinformed and may be presented with an inflated economic impact together with over-estimated job opportunities. In view of the more simplistic and affordable manner in which SAM models can be applied, organisers may be tempted to use them, rather than employing the more complicated and expensive CGE models.

The unique contribution of this article is imbedded in the fact that, within the South African context, it is the first study of its kind that aimed to determine the economic impact by means of applying more than one assessment model, that is, SAM and CGE, to the dataset of a single event. Furthermore, this article affirms that regardless of the assessment method or measuring tool applied, popular national events will doubtless have a variable impact on the economy.

In conclusion, possible future research may have to examine whether such a significant difference occurs when the same models are applied to a similar event. It is suggested that a SAM and CGE assessment should be conducted at other similar festivals to get an understanding of the impact of these models in other studies. The outcomes thereof may confirm or contradict the assumption that various models of economic assessments produce different outcomes.

\footnotetext{
Notes

The original regional SAM model and data-a regional SAM of the state of Paraná, Brazil and a matching SAM-based GEMPACK model (TPMH0060)-can be accessed at http://www.monash.edu.au/policy/archivep.htm.

2. The Western Cape Province SAM is available online from the DBSA Website and can be accessed at http://www.dbsa.org/\%285\%28ljt3xv55ifxdjc55r0urey55\%29\%29/SAM/Pages/default.aspx.

3. Percentage indicates proportion direct impact of the total impact within the trade and accommodation sector.

4. Percentage indicates proportion direct impact of the total impact within the transport and communication sector.

5. Percentage indicates proportion direct impact of the total impact within the financial and business service sector.

6. Numéraire is a basic standard by which values are measured. Acting as the numéraire is one of the functions of money in order to serve as a unit of account. This is to measure the worth of different goods and services relative to one another, i.e. in equal units. Numéraire goods are, therefore, regarded as goods with a fixed price of 1 used to facilitate calculations when only the relative prices are relevant, as in general equilibrium theory.
}

\section{LIST OF REFERENCES}

Adams, P. \& Parmenter, B. (1999). General equilibrium models. In Valuing tourism: methods and techniques. Bureau of Tourism Research Occasional Paper Number 28, Canberra, ACT. 
Blake, A. (2005). The Economic Impact of the London 2012 Olympics, Christel DeHaan Tourism and Travel Research Institute, Nottingham University Business School, Jubilee Campus, Nottingham. [0n line] Available:

http://www.utsescholarship.lib.uts.edu.au/dspace/bitstream/handle/2100/994/Impact\%202005_5. pdf? sequence=1. (Accessed 6 March 2010)

Bohlmann, H.R. \& Van Heerden, J.H. (2008). Predicting the economic impact of the 2010 FIFA World Cup on South Africa. International Journal of Sport Management and Marketing, 3(4), pp.383-396.

Cameron, M.J. (2003). The relationship between input-output (I0) analysis, social accounting matrices (SAM) and computable general equilibrium (CGE) models in a nutshell. S.I.: Global Insight Southern Africa. (Unpublished).

Chowdhury, A. \& Kirkpatrick, C. (1994). Development Policy and Planning: An Introduction to Models and Techniques. London: Routledge.

Cordier, M. \& Hecq, W. 2008. Computable general equilibrium. [On line] Available: http://www.coastalwiki.org/coastalwiki/Computable_general_equilibium. (Accessed 11 March 2010).

Crompton, J.L. (1999). Measuring the economic impact of visitors to sport tournaments and special events. Ashburn, VA: National Recreation and Park Association. [On line] Available: http://www.rpts.tamu.edu/faculty/Crompton/crompton-selected-books.shtml. (Accessed 30 November 2009)

Curtis, G. (1993). Waterlogged. Texas Monthly, 7 (Sept).

Dwyer, L., Forsyth, P. \& Spurr, R. (2006a). Assessing the economic impacts of events: a computable general equilibrium approach. Journal of Travel Research, 45(1), pp.59-66.

Dwyer, L., Forsyth, P. \& Spurr, R. (2006b). Economic impacts of sport events: a reassessment. Tourism Review International, 10(4), pp.207-216.

Edmiston, K.D. \& Thomas, M.X. (2004). The commercial music industry in Atlanta and the State of Georgia: an economic impact study. MEIEA Journal, 4(1), pp.61-82.

Erasmus, J., Slabbert, E., Saayman, M., Saayman, A. \& Oberholzer, S. (2010). Die sosio-ekonomiese impak van die besoekers aan die ABSA KKNK te Oudtshoorn 2010. Potchefstroom: Instituut vir Toerisme en Vryetydstudies, Noordwes-Universiteit (Potchefstroomkampus).

Gursoy, D., Kim, K. \& Uysal, M. (2004). Perceived impacts of festivals and special events by organisers: An extension and validation. Tourism Management, 25(2), pp.171-181.

Kruger, M., Saayman, M., Saayman, A. \& Rossouw, R. (2011). A marketing analysis and economic impact of the Old Mutual Two Oceans Marathon 2011. Potchefstroom: North-West University (Potchefstroom Campus), Institute for Tourism and Leisure Studies.

Liu, C. \& Chen, C. (2004). A Computable General Equilibrium Model of Southern Region in Taiwan: The impact of the Tainan Science-based Industrial Park. American Journal of Applied Science, 13(1), pp.220-224.

Narayan, P.K. (2004). Economic impact of tourism on Fiji's economy: empirical. Tourism Economics, 10(4), pp.419-433.

PricewaterhouseCoopers. (2005). Olympic games impact study. [0n line] Available:

http://www.culture.gov.uk/NR/rdonlyres/E88F2684-F49E-4F45-B826-

2F19F21374F8/0/0lympicGamesImpactStudy.pdf. (Accessed 8 June 2009) 
Raa, T.T. \& Sahoo, A. (2007). Competitive pressure on the Indian household: a general equilibrium approach. Economic Systems Research, 19(1), pp.57-71.

Reeves, M. (2002). Measuring the economic and social impact of the arts: a review. London: Arts Council of England.

Rivera, M.A., Hara, T. \& Kock, G. (2008). Economic impact of cultural events: the case of the Zora! Festival. Journal of Heritage Tourism, 3(2), pp.121-137.

Rolim, C. \& Kureski, R. (2006). Impacto Econômico de Curto Prazo das Universidades Estaduais Paranaenses. Curitiba. Relatório de Pesquisa realizada para a Secretaria de Ciência, Tecnologia e Ensino Superior do Estado do Paraná.

Rossouw, R. \& Saayman, M. (2011). Assimilation of tourism satellite accounts and applied general equilibrium models to inform tourism policy analysis. Tourism Economics, 17(4), pp.753-783.

Saayman, M. \& Rossouw, R. (2008). The economic value of the 2010 World Soccer Cup. Potchefstroom: Institute of Tourism and Leisure Studies, School of Economics, North-West University (Potchefstroom Campus).

Saayman, M. \& Rossouw, R. (2010). The Cape Town International Jazz Festival: more than just jazz. Development Southern Africa, 27(2), pp.255-272.

Saayman, M., Rossouw, R. \& Saayman, A. (2008). Economic impact of visitor spending at the Cape Argus Pick 'n Pay Cycle Tour. Africa Insight, 38(3), pp.100-122.

Schwarm, W. \& Cutler, H. (2003). Building small city and town SAMS and CGE models. RURDS, 15(2), pp.132-147.

Snowball, J.D. (2000). Towards more accurate measurement of the value of the arts to society: economic impact and willingness to pay studies at the Standard Bank National Arts Festival. Unpublished MA thesis. Grahamstown: Rhodes University.

URS Finance \& Economics. (2004). Economic impact of the Rugby World Cup 2003 on the Australian economy - post analysis. [0n line] Available:

http://fulltext.ausport.gov.au/fulltext/2004/feddep/FinalEconomic/mpactOfRWC2003.pdf. (Accessed 12 July 2009)

Wagner, J.E. (1997). Estimating the economic impact of tourism. Annals of Research, 24(3), pp.592608.

White, W.A. \& Patriquin, M.N. (2003). Agenda: A journal of policy analysis and reform: Volume 13. Canberra: Australian National University, Faculty of Economics and Commerce.

Wilson, J.H. \& Raymond, R. (1973). The economic impact of a university upon the local economy. Annals of Regional Science, 7(2), pp.130-142. 